\title{
Factors Influencing The Revenue Of Broiler Open House System Partnership Corporate X In Indonesia
}

\author{
Niswatin Hasanah $^{(1)}$ \& Zaenal Fanani ${ }^{(2)}$ \\ ${ }^{1}$ Politeknik Negeri Jember, ${ }^{2}$ Universitas Brawijaya \\ E-mail: 'niswatinhasanah122@yahoo.com,2prof_zaenalfanani@yahoo.co.id,
}

Received: 30 January 2018; Revised: 12 March 2018; Accepted: 8 May 2018

\begin{abstract}
Abstrack
The objective of research is to understand factors influencing the revenue of broiler farming. Research starts from June to July 2015. Method of research is case study. Data collection technique includes observation and interview. The interview is conducted with 30 broiler farmers selected through total sampling and also corporation X In Kediri Indonesia. Data analysis tool involves descriptive analysis, economic analysis and regression analysis with SPSS16. Result of research indicates that various strata can be arranged based on chicken ownership (breeding capacity), respectively 3,00012,000 chickens for Strata I, 12,000-27,000 chickens for Strata II, and > 30,000 chickens for Strata III. Production cost, revenue and profit in Strata III are greater than those in Strata I and II. Factors influencing the revenue of breeder on period 1 -6 include feed cost, broiler sale and bonus. Based on financial analysis against broiler breeding, the breeding is profitable and also reliable pursuant to what has been shown by financial result.
\end{abstract}

Key words: financial analysis, broiler breeding, partnership, feed cost, bonus, broiler turnover

\section{Introduction}

Breeding work sustainability can be estimated from the description of its financial aspects. The capacity of breeding work in developing the capital is usually measured from the parameters of investment such as work capacity in developing initial capital greater than bank interest, work profit in future years, and others. In other words, breeding work can be said as sustainable itself if profit is greater than cost expended. Therefore, all matters must be ens ured as financially reliable (Fatah, 1994). Some factors influencing the revenue of broiler breeding are DOC price, feed price, medicine \& vaccine cost, breeder age, and breeding experience. This background has encouraged the author to conduct a research entitled with "Factors Influ- encing The Revenue of Broiler Plasma Breeding in Open House System Partnership with corporate X of Kediri Indonesia" in order to understand the financial analysis against broiler plasma breeding in open house system partnership with corporate $\mathrm{X}$ in Kediri Regency. Every breeding work has been oriented toward the achievement of maximum profit. Some methods of financial analysis are used such as Break Even Point (BEP) and Revenue Cost Ratio (R/C Ratio). Factors influencing the revenue of broiler breeder are understood. Financial analysis helps breeders to obtain information about how far is their work to become successful business.

\section{Material and Methods}

Method of research is case study, whereas 
data collection involves observation and interview.

\section{Data Collection Method}

Data source involves primary and secondary. Primary data are obtained from interfacial meeting and dialog. Questionnaire is distributed to respondents, respectively broiler breeders who participate into partnership program with corporate X, Ltd in Kediri Regency Region, Indonesia. Secondary data are derived from scientific reports, notes and documents in related institutions, and also acquired from any refe rences relevant to this research. Research location is determined by purposive sampling whereas sample population is determined through total sampling. The sample includes broiler breeders who participate into partnership program with corporate $\mathrm{X}$ in Kediri Regency Region, Indonesia. The type of partnership is Open House System involving 30 broiler breeders. The breeders are assigned into three strata based on their chicken ownership, respectively Strata I (3,000 -12,000 chickens), Strata II (12,000-27,000 chickens), and Strata III (> 30,000 chickens).

\section{Data Analysis}

Data analysis is a descriptive analysis to understand the condition of broiler farming works, the characteristic of farmers, the implementation of core-plasma, partnership and the counting of the composition, the analysis of production and profit and the analysis of finance and SPSS16 software regression.

\section{Regression Equations}

Multiple Regression Analysis on Period 1:

$Y_{1}=a+b_{1}$ feed $_{1}+b_{2}$ OVK $_{1}+b_{3}$ sale $_{1}+b_{4}$ bonus $_{1}+\mathrm{b}_{5}$ harvest weight ${ }_{1}+\mathrm{b}_{6}$ age $+\mathrm{b}_{7}$ education $+b_{8}$ experience $+b_{9}$ number of member $+b_{10}$ land mastery $+b_{11}$ work scale $+\mathrm{e}$

Multiple Regression Analysis on Period 2:

$\mathrm{Y}_{2}=\mathrm{a}+\mathrm{b}_{1}$ feed $_{2}+\mathrm{b}_{2} \mathrm{OVK}_{2}+\mathrm{b}_{3}$ sale $_{2}+\mathrm{b}_{4}$ bonus $_{2}+b_{5}$ harvest weight $2+b_{6}$ age $+b_{7}$ education $+b_{8}$ experience $+b_{9}$ number of member $+b_{10}$ land mastery $+b_{11}$ work scale $+\mathrm{e}$

Multiple Regression Analysis on Period 3:
$\mathrm{Y}_{3}=\mathrm{a}+\mathrm{b}_{1}$ feed $_{3}+\mathrm{b}_{2}$ OVK $_{3}+\mathrm{b}_{3}$ sale $_{3}+\mathrm{b}_{4}$ bonus $_{3}+b_{5}$ harvest weight $3+b_{6}$ age $+b_{7}$ education $+b_{8}$ experience $+b_{9}$ number of member $+b_{10}$ land mastery $+b_{11}$ work scale $+\mathrm{e}$

Multiple Regression Analysis on Period 4:

$\mathrm{Y}_{4}=\mathrm{a}+\mathrm{b}_{1}$ feed $_{4}+\mathrm{b}_{2}$ OVK $_{4}+\mathrm{b}_{3}$ sale $_{4}+\mathrm{b}_{4}$ bonus $_{4}+b_{5}$ harvest weight $4+b_{6}$ age $+b_{7}$ education $+b_{8}$ experience $+b_{9}$ number of member $+b_{10}$ land mastery $+b_{11}$ work scale $+\mathrm{e}$

Multiple Regression Analysis on Period 5:

$\mathrm{Y}_{5}=\mathrm{a}+\mathrm{b}_{1}$ feed $_{5}+\mathrm{b}_{2}$ OVK $_{5}+\mathrm{b}_{3}$ sale $_{5}+\mathrm{b}_{4}$ bonus $_{5}+b_{5}$ harvest weight $5+b_{6}$ age $+b_{7}$ education $+b_{8}$ experience $+b_{9}$ number of member $+b_{1} 0$ land mastery $+b_{1} 1$ work scale $+\mathrm{e}$

Multiple Regression Analysis on Period 6:

$\mathrm{Y}_{6}=\mathrm{a}+\mathrm{b}_{1}$ feed $_{6}+\mathrm{b}_{2}$ OVK $_{6}+\mathrm{b}_{3}$ sale $_{6}+\mathrm{b}_{4}$ bonus $_{6}+\mathrm{b}_{5}$ harvest weight $_{6}+\mathrm{b}_{6}$ age $+\mathrm{b}_{7}$ education $+b_{8}$ experience $+b_{9}$ number of member $+b_{1} 0$ land mastery $+b_{11}$ work scale $+\mathrm{e}$

\section{Results and Discussion \\ Production Cost, Revenue and Profit}

Production cost and revenue may change over period. The change of production cost is caused by the difference across strata in terms of feed quantity, medicine and DOC quality. The percentage of production cost across strata is ordered as follows: $74.55 \%$ for Strata I, $76.29 \%$ for Strata II, and $75.44 \%$ for Strata III. The highest revenue is obtained from chicken sal e and FCR bonus. The following is pictures for production cost, revenue and profit.

Total revenue of broiler breeding in

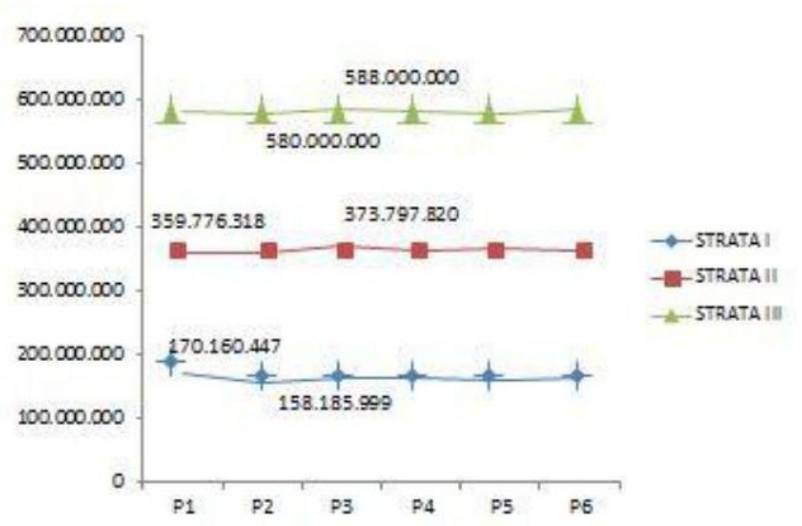

Figure 1 Production cost over periode 


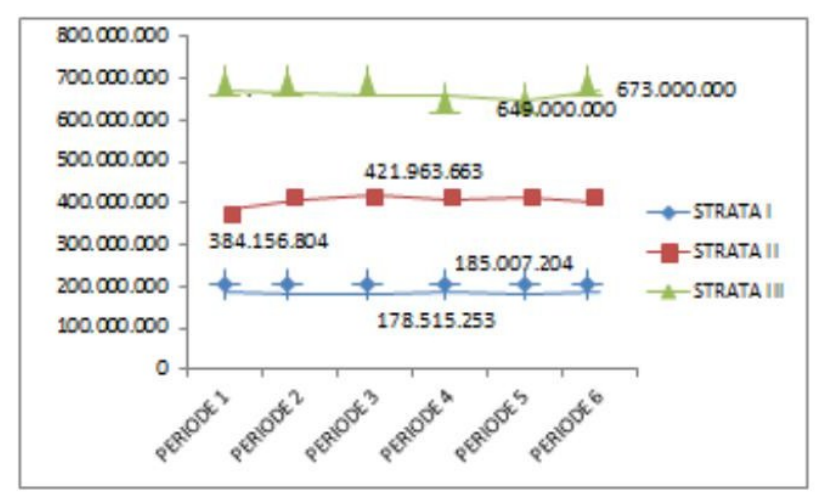

Figure 2 Revenue over periode

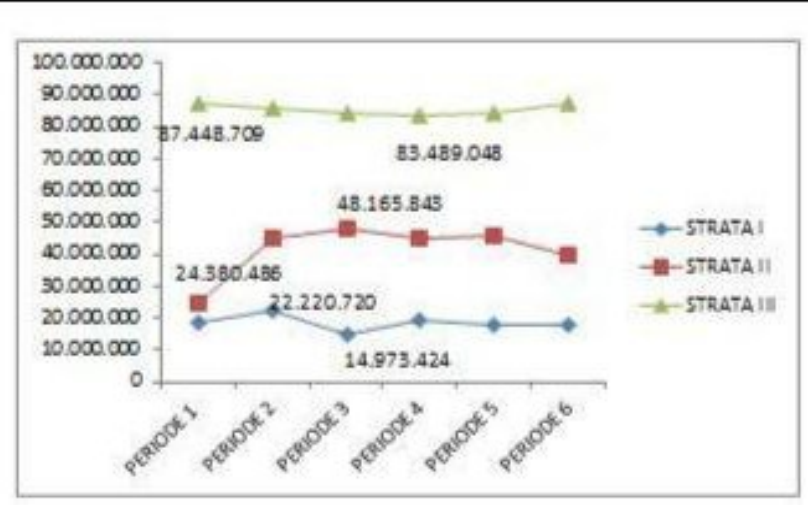

Figure 3 Profit over periode

open house syste m partnership with X, Ltd is fluctuated. It occurs because the sale of the living broiler is always fluctuated over period either for its price or quantity. Different revenue obtained may be caused by the difference of mortality rate, Food Consumption Rate (FCR), and bonus standard. Siregar (2009) has stated that the lower FCR means smaller cost expended to purchase the feed. In contrast, the higher FCR means the higher cost to buy the feed. Such difference is also caused by different $h$ arvest weight and also triggered by the fact that the harvest price of every weight can also be different.

\section{Feed}

Result of regression against feed on Period 1 indicates that coefficient of regression is shown by $\square=-1.822$, meaning that the decrease of feed price for 1 unit will increase revenue of breeders to 1.822 . Feed cost variable in this research is the cost expended by breeders to procure the feed for all livestock they breed. Within the context of broiler breeding work, feed cost is the biggest cost because it represents $70 \%$ of production cost total. It is supported by Rasyaf (2001) through a claim that feed is a factor that influences the change of broiler growth rate. In broiler breeding work, feed plays very important role in securing the feasibilit $y$ of the work. Feed is always important, but more important issue is feed price.

\section{Broiler Sale}

Result of regression against broiler sale on Period 1 has shown that coefficient of regression is shown by $\square=2.498$, meaning that every broiler sale increase on Period 1 to one unit will increase revenue of breeders to 2.498 . This fact is supported by Widodo (2001) in analysis of regression which indicates that revenue from broiler breeding has a signific ant effect on the income of broiler breeders and also has a positive relationship with it, as shown by $\square=2.976$. The result of meat/chicken sale is the biggest component of revenue because sale result can suppress production cost and also maximize

Table 1 Factors influencing the revenue

\begin{tabular}{|c|c|c|c|c|c|c|}
\hline Influencing & Period & Period 2 & Period 3 & Period 4 & Period 5 & Period 6 \\
\hline Feed & $-1,822$ & $-2,879$ & $-1,950$ & $-2,574$ & $-2,418$ & $-1,934$ \\
\hline Broiler sale & 2,498 & 2,827 & 2,271 & 2,575 & 2,604 & 2,645 \\
\hline Bonus & 0,571 & 0,177 & 0,122 & 0,216 & 0,142 & 0,221 \\
\hline $\begin{array}{l}\text { Nilai } \\
\text { koefisien } \\
\text { determinasi }\end{array}$ & $\begin{array}{l}\text { Period } \\
1\end{array}$ & Period 2 & Period 3 & Period 4 & Period 5 & Period 6 \\
\hline $\mathrm{R}$ square $\left(\mathrm{R}^{2}\right)$ & 0,779 & 0,791 & 0,681 & 0,676 & 0,778 & 0,732 \\
\hline Adj R Square & 0,767 & 0,785 & 0,669 & 0,662 & 0,764 & 0,791 \\
\hline
\end{tabular}


profit as what breeders expect.

\section{Bonus}

Result of regression against bonus on Period 1 indicates that coefficient of regression is shown by $\square=0.571$, meaning that every bonus increase on Period 1 to one unit will increase revenue of breeders to 0.571 . The so called bonus may include FCR bonus, food discount bonus, transport bonus, and mortality bonus. It is supported by Saleh (2006) who says that FCR bonus, food discount bonus, transport bonus, and mortality bonus can influence revenue of broiler breeders for $12.9 \%$.

\section{Conclusion}

Based on the result and discussion previously stated, it is concluded that: (1) For production cost at Strata I, II and III, the order is arranged as follows: IDR 989,186,946, IDR 2,192,126,007, and IDR 3,500,508,082. (2) For revenue at Strata I, II, III, and IV, the order is arranged as follows: IDR 943,116,780, IDR $1,553,636,211$, IDR 1,908,201,667 and IDR 2,461,892,374. (3) For profit at Strata I, II, III, and IV, the order is arranged as follows: IDR $83,327,588$, IDR 122,905,847, IDR 166,139,085, and IDR 223,574,152. (4) Factors influencing the revenue in every period are feed cost, revenue of broiler sale and bonus.

\section{Reference}

Sigit, S. (1990). Analisa Break Event. Yogyakarta: BPFE Fakultas Ekonomi Universitas Gadjahmada.

Suastina, I.G.P.B., \& Kayana, I.G.N. (2005). Analisis Finansial Usaha Agribisnis Peternakan Sapi Daging (Suatu Studi Kasus), (Online), (http:// www.google.com/url? sa $=$ t\&rct $=\mathrm{j} \& \mathrm{q}=$ analisa\%20npv20peternakan20broier\&source $=$ web\&cd $=7 \& \mathrm{cad}=$ rja\&uact $=8 \&$ ved $=0 \mathrm{CF}$ cQFjAG\&url=http://portalgaruda.org/dow nload_article.php\%3Farticle\%3D19700\% 26val\%3D1236\&ei=bJEiU_SMMsrJkAe1 n4Bg\&usg=AFQjCNHGe5PfxotRPiRZzp HepseUVuXmNg\&sig2 $=\mathrm{e} 6 \mathrm{xYCmNiSyU}$ GUX_767jQjA\&bvm=bv.62922401,d.eW $0)$.

Sudana, I.M. (2009). Manajemen Keuangan.
Surabaya: Airlangga University Press.

Umar, H. (2003). Studi Kelayakan Bisnis, Edisi 2. Jakarta: PT. Gramedia Pustaka Utama.

Widodo, W. \& Ngapuli, P. (1989). Pengantar Ekonomi Pertanian dan Peternakan, Nuffic. Malang: Universitas Brawijaya

Yunus, R. 2009. Analisis Efisiensi Produksi Usaha Peternakan Ayam Ras Pedaging Pola Kemitraan dan Mandiri di Kota Palu Provinsi Sulawesi Tengah. (Online), (http:// eprints.undip.ac.id/18874/1/Rita_Yunus.pd f) 